\title{
THE BARENBLATT - ZHELTOV - KOCHINA MODEL WITH ADDITIVE WHITE NOISE IN QUASI-SOBOLEV SPACES
}

G. A. Sviridyuk ${ }^{1}$, sviridyuk@susu.ac.ru,

N. A. Manakova ${ }^{1}$, manakova@susu.ac.ru,

${ }^{1}$ South Ural State University, Chelyabinsk, Russian Federation.

In order to carry over the theory of linear stochastic Sobolev-type equations to quasiBanach spaces, we construct a space of differentiable quasi-Sobolev "noises" and establish the existence and uniqueness of a classical solution to the Showalter - Sidorov problem for a stochastic Sobolev-type equation with a relatively $p$-bounded operator. Basing on the abstract results, we study the Barenblatt - Zheltov - Kochina stochastic model with the Showalter - Sidorov initial condition in quasi-Sobolev spaces with an external action in the form of "white noise".

Keywords: Sobolev-type equations; Wiener process; Nelson-Gliklikh derivative; white noise; quasi-Sobolev spaces; Barenblatt - Zheltov - Kochina stochastic equation.

\section{Introduction}

Consider the space $l_{q}$ of sequences $u=\left(u_{1}, u_{2}, \ldots\right)$ of real numbers with the quasi-norm

$$
{ }_{q}\|u\|=\left(\sum_{k=1}^{\infty}\left|u_{k}\right|^{q}\right)^{\frac{1}{q}}
$$

where $q \in \mathbb{R}_{+}$. The definition of quasi-norm $\mathfrak{u}\|\cdot\|$ on a real subspace $\mathfrak{U}$ differs from the definition of the norm $\|\cdot\|_{\mathfrak{U}}$ only in the triangle inequality axiom

$$
\mathfrak{u}\|u+v\| \leq C(\mathfrak{u}\|u\|+\mathfrak{u}\|v\|),
$$

with a constant $C \geq 1$. In the case of the space $l_{q}$ the constant is $C=2^{\frac{1-q}{q}}$ for $q \in(0,1)$ and $C=1$ for $q \in[1,+\infty)$. It is well-known (see Lemma 3.10.1 in [1] for instance) that the quasi-normed space $\mathfrak{U}=(\mathfrak{U}, \mathfrak{U}\|\cdot\|)$ is not in general normable although metrizable; that is, on the quasi-normed space $\mathfrak{U}$ there is a metric which agrees with some power of the quasi-norm $\mathfrak{u}\|\cdot\|$. Hence, the concepts of fundamental sequence and completion make sense in a quasi-normed space. A complete quasi-normed space is called a quasi-Banach space. Henceforth, for definiteness, we regard the Banach spaces $l_{q}$ with $q \in[1,+\infty)$ as quasi-Banach spaces.

Given a monotone sequence $\left\{\lambda_{k}\right\} \subset \mathbb{R}_{+}$with $\lim _{k \rightarrow \infty} \lambda_{k}=+\infty$, construct the quasiSobolev space

$$
l_{q}^{m}=\left\{u=\left(u_{1}, u_{2}, \ldots\right): \sum_{k=1}^{\infty}\left(\lambda_{k}^{\frac{m}{2}}\left|u_{k}\right|\right)^{q}<\infty\right\}, m \in \mathbb{R}, q \in \mathbb{R}_{+} .
$$


This is a quasi-Banach space with the quasi-norm

$$
{ }_{q}^{m}\|u\|=\left(\sum_{k=1}^{\infty}\left(\lambda_{k}^{\frac{m}{2}}\left|u_{k}\right|\right)^{q}\right)^{\frac{1}{q}}
$$

moreover [2], the embedding $l_{q}^{m} \hookrightarrow l_{q}^{n}$ is dense and continuous for $m \geq n$. On $l_{q}^{m}$ define the Laplace quasi-operator $\Lambda u=\left(\lambda_{1} u_{1}, \lambda_{2} u_{2}, \ldots\right)$, which is continuous as $\Lambda: l_{q}^{m+2} \rightarrow l_{q}^{m}$ for all $q \in \mathbb{R}_{+}$and $m \in \mathbb{R}$. The Barenblatt - Zheltov - Kochina model, describing the filtration of fluid in a medium with cracks and pores, in quasi-Sobolev spaces reads as

$$
(\lambda-\Lambda) u_{t}=\alpha \Lambda u+f
$$

Sufficient conditions were determined in [2] for the existence of a unique solution $u$ in $C\left([0, \tau) ; l_{q}^{m+2}\right) \cap C^{1}\left((0, \tau) ; l_{q}^{m+2}\right)$ to the Showalter - Sidorov problem

$$
(\lambda-\Lambda)\left(u(0)-u_{0}\right)=0
$$

for $(0.1)$ with arbitrary $\tau, q \in \mathbb{R}_{+}, m, \lambda \in \mathbb{R}, u_{0} \in l_{q}^{m+2}$, and $f \in C^{1}\left([0, \tau) ; l_{q}^{m}\right)$.

The goal of this note is, firstly, to extend the concept of white noise [3] to the spaces $l_{q}^{m}$, and secondly, to consider the stochastic version [4] of problem (0.1), (0.2) in these spaces.

\section{White Noise in Quasi-Sobolev Spaces}

The spaces $\mathbf{C}^{l} \mathbf{L}_{2}$ of random processes $\left(\mathbf{C}^{l} \mathbf{L}_{2}(\varepsilon, \tau)\right.$ with intervals $\left.(\varepsilon, \tau) \subset \mathbb{R}\right)$ whose Nelson - Gliklikh derivatives through order $l \in\{0\} \cup \mathbb{N}$ are almost surely (a.s.) continuous on $(\varepsilon, \tau)$ (that is, a.s. all trajectories of these derivatives are continuous on $(\varepsilon, \tau)$ ) were considered for the first time in [4]. An example is the Wiener process

$$
\beta(t)=\sum_{k=0}^{\infty} \xi_{k} \sin \frac{\pi}{2}(2 k+1) t
$$

modeling Brownian motion on a line in the Einstein - Smoluchowski theory because

$$
\stackrel{o}{\beta}^{(k)}(t)=(-1)^{k+1} \prod_{i=1}^{k-1}(2 i-1)(2 t)^{-k} \beta(t) \text { for all } t \in \mathbb{R}_{+} \text {and } k \in \mathbb{N}
$$

according to Gliklikh's theorem ([4], Theorem 1.2). Recall that $\xi_{k}$ are independent Gaussian variables with expectation $\mathbf{E} \xi_{k}=0$ and variance $\mathbf{D} \xi_{k}=\left[\frac{\pi}{2}(2 k+1)\right]^{-2}$, for $k \in\{0\} \cup \mathbb{N}$.

Introduce now the space $\mathbf{l}_{q}^{m} \mathbf{L}_{2}$ of sequences of random variables $\omega=\left(\omega_{1}, \omega_{2}, \ldots\right)$ with the quasi-norm

$$
{ }_{q}^{m}|\|\omega\||=\left(\sum_{k=1}^{\infty}\left(\lambda_{k}^{m} \mathbf{D} \omega_{k}\right)^{\frac{q}{2}}\right)^{\frac{1}{q}}, \quad q \in \mathbb{R}_{+}, m \in \mathbb{R} .
$$

These $\mathbf{l}_{q}^{m} \mathbf{L}_{2}$ are obviously quasi-Banach spaces, and by analogy with quasi-Sobolev spaces we call them quasi-Sobolev stochastic spaces. Indeed, the embedding $\mathbf{l}_{q}^{m} \mathbf{L}_{2} \hookrightarrow \mathbf{l}_{q}^{n} \mathbf{L}_{2}$ is dense 
and continuous for all $m \geq n$ and $q \in \mathbb{R}_{+}$, and in addition, the Laplace quasi-operator $\Lambda: \mathbf{l}_{q}^{m+2} \mathbf{L}_{2} \rightarrow \mathbf{l}_{q}^{m} \mathbf{L}_{2}$ is linear, continuous, and even continuously invertible for all $m \in \mathbb{R}$ and $q \in \mathbb{R}_{+}$.

Furthermore, introduce the spaces $\mathbf{C}^{l} \mathbf{l}_{q}^{m} \mathbf{L}_{2}$ (meaning $\mathbf{C}^{l} \mathbf{l}_{q}^{m} \mathbf{L}_{2}(\varepsilon, \tau)$, where $(\varepsilon, \tau) \subset \mathbb{R}$ ) of random processes $\eta=\left(\eta_{1}, \eta_{2}, \ldots\right)$ with $\eta_{k}=\eta_{k}(t)$ for $t \in(\varepsilon, \tau)$ and $k \in \mathbb{N}$, whose Nelson - Gliklikh derivatives through order $l \in\{0\} \cup \mathbb{N}$ are a.s. continuous on $(\varepsilon, \tau)$. An example is the Wiener process

$$
W_{q S}=\left(\beta_{1}, \beta_{2}, \ldots\right),
$$

where $\beta_{k}=\beta_{k}(t)$ for $t \in \mathbb{R}_{+}$are Brownian motions of the form (1.1). By Gliklikh's theorem, $W_{q S} \in \mathbf{C}^{l} \mathbf{1}_{q}^{m} \mathbf{L}_{2}$ for all $l \in\{0\} \cup \mathbb{N}$ provided that the series

$$
\sum_{k=1}^{\infty} \lambda_{k}^{\frac{m q}{2}}
$$

converges. To find conditions for this convergence is the subject of future research. Here we observe that for $m=-2 q^{-1}$ and $\lambda_{k}=k^{2}$ the series (1.4) converges. Following [3, 4], we refer to the Nelson - Gliklikh derivative $\stackrel{o}{W}_{q S}(t)=(2 t)^{-1} W_{q S}(t)$ of the Wiener process $W_{q S}(t)$ as white noise.

\section{The Barenblatt - Zheltov - Kochina Stochastic Model}

Take $\mathfrak{U}=\mathbf{l}_{q}^{m+2} \mathbf{L}_{2}$ and $\mathfrak{F}=\mathbf{l}_{q}^{m} \mathbf{L}_{2}$ with $m \in \mathbb{R}$ and $q \in \mathbb{R}_{+}$. Consider the Barenblatt Zheltov - Kochina stochastic model with the Showalter - Sidorov condition (0.1), (0.2). Fixing $\alpha, \lambda \in \mathbb{R}$, construct the operators $L=\lambda-\Lambda$ and $M=\alpha \Lambda$, where $\Lambda$ is the Laplace quasi-operator. Define the operator $\Lambda^{-1} u=\left\{\lambda_{k}^{-1} u_{k}\right\}$ and call it the Green quasi-operator. Consider $L, M \in \mathcal{L}(\mathfrak{U} ; \mathfrak{F})$ (see [2]); moreover, $L$ is a Fredholm operator for all $\lambda \in \mathbb{R}$. Therefore, we can reduce the Barenblatt - Zheltov - Kochina stochastic equation (0.1) to the linear stochastic Sobolev-type equation

$$
L \stackrel{o}{\eta}=M \eta+N w
$$

where $\eta=\eta(t)$ is the required random process, while $w=w(t)$ is a given one, on the interval $(0, \tau)$. The operator $N \in \mathcal{L}(\mathfrak{U} ; \mathfrak{F})$ is to be specified below.

Introduce the $L$-resolvent set $\rho^{L}(M)=\left\{\mu \in \mathbb{C}:(\mu L-M)^{-1} \in \mathcal{L}(\mathfrak{F} ; \mathfrak{U})\right\}$ and the $L$ spectrum $\sigma^{L}(M)=\mathbb{C} \backslash \rho^{L}(M)$ of the operator $M$. If the $L$-spectrum $\sigma^{L}(M)$ of $M$ is bounded then $M$ is called an $(L, \sigma)$-bounded operator. In this case there exist projections

$$
P=\frac{1}{2 \pi i} \int_{\gamma} R_{\mu}^{L}(M) d \mu \in \mathcal{L}(\mathfrak{U}), \quad Q=\frac{1}{2 \pi i} \int_{\gamma} L_{\mu}^{L}(M) d \mu \in \mathcal{L}(\mathfrak{F}) .
$$

Here $R_{\mu}^{L}(M)=(\mu L-M)^{-1} L$ is the right and $L_{\mu}^{L}(M)=L(\mu L-M)^{-1}$ is the left $L$ resolution of $M$, while the closed contour $\gamma \subset \mathbb{C}$ bounds a region including $\sigma^{L}(M)$. Put $\mathfrak{U}^{0}=\operatorname{ker} P, \mathfrak{U}^{1}=\operatorname{im} P, \mathfrak{F}^{0}=\operatorname{ker} Q$, and $\mathfrak{F}^{1}=\operatorname{im} Q$, and denote by $L_{k}$ and $M_{k}$ the restrictions of $L$ and $M$ to $\mathfrak{U}^{k}$ for $k=0,1$.

Theorem 1. (Splitting theorem [5]) If $M$ is an $(L, \sigma)$-bounded operator then

(i) we have $L_{k}\left(M_{k}\right) \in \mathcal{L}\left(\mathfrak{U}^{k} ; \mathfrak{F}^{k}\right)$ for $k=0,1$; 
(ii) there exist operators $M_{0}^{-1} \in \mathcal{L}\left(\mathfrak{F}^{0} ; \mathfrak{U}^{0}\right)$ and $L_{1}^{-1} \in \mathcal{L}\left(\mathfrak{F}^{1} ; \mathfrak{U}^{1}\right)$.

Construct the operators $H=M_{0}^{-1} L_{0} \in \mathcal{L}\left(\mathfrak{U}^{0}\right)$ and $S=L_{1}^{-1} M_{1} \in \mathcal{L}\left(\mathfrak{U}^{1}\right)$. An operator $M$ is called $(L, p)$-bounded, with $p \in\{0\} \cup \mathbb{N}$, whenever $\infty$ is a removable singular point (that is, $H \equiv \mathbb{O}$ when $p=0$ ) or a pole of order $p \in \mathbb{N}$ (that is, $H^{p} \neq \mathbb{O}$ and $\left.H^{p+1} \equiv \mathbb{O}\right)$ of the $L$-resolution $(\mu L-M)^{-1}$ of $M$.

Take an $(L, p)$-bounded operator $M$ with $p \in\{0\} \cup \mathbb{N}$. Impose on (2.1) the Showalter - Sidorov initial condition

$$
\left[R_{\alpha}^{L}(M)\right]^{p+1}\left(\eta(0)-\xi_{0}\right)=0 .
$$

Below we consider also the weak Showalter - Sidorov condition (in the sense of Krein):

$$
\lim _{t \rightarrow 0+}\left[R_{\alpha}^{L}(M)\right]^{p+1}\left(\eta(t)-\xi_{0}\right)=0 .
$$

Definition 1. Refer to a random process $\eta \in \mathbf{C}^{1} \mathbf{l}_{q}^{m} \mathbf{L}_{2}(0, \tau)$ as a (classical) solution to (2.1) whenever almost surely all its trajectories satisfy (2.1) for all $t \in(0, \tau)$. Refer to a solution $\eta=\eta(t)$ to (2.1) as a (classical) solution to problem (2.1), (2.2) whenever it also satisfies (2.2).

Remark 1. In the case that $M$ is $(L, 0)$-bounded, conditions (2.2) and (2.3) are equivalent to the following conditions respectively:

$$
L\left(\eta(0)-\xi_{0}\right)=0 \text { and } \lim _{t \rightarrow 0+} L\left(\eta(t)-\xi_{0}\right)=0 .
$$

Theorem 2. Given an $(L, p)$-bounded operator $M$ with $p \in\{0\} \cup \mathbb{N}$, for every $N \in \mathcal{L}(\mathfrak{U} ; \mathfrak{F})$, every random processes $w=w(t)$ satisfying $(\mathbb{I}-Q) N w \in \mathbf{C}^{p+1} \mathbf{l}_{q}^{m} \mathbf{L}_{2}$ and $Q N w \in \mathbf{C l}_{q}^{m} \mathbf{L}_{2}$, and every random quantity $\xi_{0} \in \mathbf{l}_{q}^{m} \mathbf{L}_{2}$ independent of $w$ for all fixed $t \in(0, \tau)$ there exists a unique solution $\eta \in \mathbf{C}^{1} \mathbf{l}_{q}^{m} \mathbf{L}_{2}$ to problem (2.1), (2.2), which, moreover, is of the form

$$
\eta(t)=U^{t} \xi_{0}+\int_{0}^{t} U^{t-s} L_{1}^{-1} Q N w(s) d s-\sum_{n=0}^{p} H^{q} M_{0}^{-1}(\mathbb{I}-Q) N \stackrel{o}{w}{ }^{(n)}(t) .
$$

Remark 2. We can prove Theorem 2 by analogy with the deterministic case [5]. However, as the white noise $w(t)=(2 t)^{-1} W_{q S}(t)$ is not differentiable at $t=0$, it cannot appear in the right-hand side of (2.1). A way around this obstacle, proposed in [4, 6, 7], relies on limit passage. To use this approach, rearrange the second term in the right-hand side of (2.5) as

$$
\begin{gathered}
\int_{\varepsilon}^{t} U^{t-s} L_{1}^{-1} Q N \stackrel{o}{W_{q S}}(s) d s= \\
L_{1}^{-1} Q N W_{q S}(t)-U^{t-\varepsilon} L_{1}^{-1} Q N W_{q S}(\varepsilon)+S P \int_{\varepsilon}^{t} U^{t-s} L_{1}^{-1} Q N W_{q S}(s) d s .
\end{gathered}
$$

Integration by parts makes sense for arbitrary $\varepsilon \in(0, t)$, with $t \in \mathbb{R}_{+}$, by the definition of Nelson - Gliklikh derivative. Passing in (2.6) to the limit as $\varepsilon \rightarrow 0$, we obtain

$$
\int_{0}^{t} U^{t-s} L_{1}^{-1} Q N \stackrel{o}{W_{q S}}(s) d s=L_{1}^{-1} Q N W_{q S}(t)+S P \int_{0}^{t} U^{t-s} L_{1}^{-1} Q N W_{q S}(s) d s .
$$


Proceed to problem (2.3) for the stochastic Barenblatt - Zheltov - Kochina equation on $\mathbb{R}_{+}$,

$$
L \stackrel{o}{\eta}=M \eta+N \stackrel{o}{W}_{q S},
$$

where $W_{q S}=W_{q S}(t)$ is a Wiener process. Then the following statement holds.

Lemma 1. For all $\lambda \in \mathbb{R}$ and $\alpha \in \mathbb{R} \backslash\{0\}$ the operator $M$ is $(L, 0)$-bounded.

Theorem 3. For all $\lambda \in \mathbb{R}, \alpha \in \mathbb{R} \backslash\{0\}, N \in \mathcal{L}(\mathfrak{U} ; \mathfrak{F})$, and $\xi_{0} \in \mathbf{l}_{q}^{m} \mathbf{L}_{2}$ independent of $W_{q S}$ there exists a unique solution $\eta=\eta(t)$ to problem (2.2), (2.7), which, moreover, is of the form

$$
\eta(t)=U^{t} \xi_{0}+L_{1}^{-1}\left[Q N W_{q S}(t)+M_{1} \int_{0}^{t} U^{t-s} L_{1}^{-1} Q N W_{q S}(s) d s\right]-M_{0}^{-1}(\mathbb{I}-Q) N \stackrel{o}{W_{q S}}(t) .
$$

Here

$$
U^{t}= \begin{cases}\sum_{k=1}^{\infty} e^{\mu_{k} t}<\cdot, e_{k}>e_{k}, & \text { if } \lambda \neq \lambda_{k}, k \in \mathbb{N} ; \\ \sum_{k \neq l} e^{\mu_{k} t}<\cdot, e_{k}>e_{k}, & \text { if } \exists l \in \mathbb{N}: \lambda=\lambda_{l},\end{cases}
$$

with the points $\mu_{k}=\frac{\alpha \lambda_{k}}{\lambda-\lambda_{k}}$ of the $L$-spectrum of $M$, the sequence $\left\{\xi_{0 k}\right\}=\xi_{0} \in \mathbf{l}_{q}^{m} \mathbf{L}_{2}$, and the vector $e_{k}=(0, \ldots, 0,1,0, \ldots)$ in which the unity appears in slot $k$. The operators $L_{1}^{-1}$ and $M_{1}^{-1}$ are defined as

$$
\begin{gathered}
L_{1}^{-1} \zeta=\left\{\begin{array}{l}
\left\{\left(\lambda-\lambda_{k}\right)^{-1} \zeta_{k}\right\}, \text { if } \lambda \neq \lambda_{k} \text { for all } k \in \mathbb{N} ; \\
\left(\left(\lambda-\lambda_{1}\right)^{-1} \zeta_{1}, \ldots,\left(\lambda-\lambda_{l-1}\right)^{-1} \zeta_{l-1}, 0,\left(\lambda-\lambda_{l+1}\right)^{-1} \zeta_{l+1}, \ldots\right), \text { if } \exists l \in \mathbb{N}: \lambda=\lambda_{l} ;
\end{array}\right. \\
M_{1} \eta=\left\{\begin{array}{l}
\left\{\alpha \lambda_{k} \eta_{k}\right\}, \text { if } \lambda \neq \lambda_{k} \text { for all } k \in \mathbb{N} ; \\
\left(\alpha_{1} \lambda_{1} \eta_{1}, \ldots, \alpha_{l-1} \lambda_{l-1} \eta_{l-1}, 0, \alpha_{l+1} \lambda_{l+1} \eta_{l+1}, \ldots\right), \text { if } \exists l \in \mathbb{N}: \lambda=\lambda_{l} .
\end{array}\right. \\
M_{0}^{-1} \zeta=\left\{\begin{array}{l}
\{0\}, \text { if } \lambda \neq \lambda_{k} \text { for all } k \in \mathbb{N} ; \\
\left(0, \ldots, 0,\left(\alpha_{l} \lambda_{l}\right)^{-1} \zeta_{l}, 0, \ldots\right), \text { if } \exists l \in \mathbb{N}: \lambda=\lambda_{l} .
\end{array}\right.
\end{gathered}
$$

The projection is

$$
Q=\left\{\begin{array}{l}
\sum_{k=1}^{\infty}<\cdot, e_{k}>e_{k}, \text { if } \lambda \neq \lambda_{k} \text { for all } k \in \mathbb{N} \\
\sum_{k=1, k \neq l}^{\infty}<\cdot, e_{k}>e_{k}, \text { if } \exists l \in \mathbb{N}: \lambda=\lambda_{l}
\end{array}\right.
$$

\section{References}

1. Bergh J., Löfström J. Interpolation Spaces. An Introduction. Berlin, Heidelberg, N.Y., Springer-Verlag, 1978.

2. Keller A.V., Al-Delfi J.K. Holomorphic Degenerate Groups of Operators in QuasiBanach Spaces. Bulletin of the South Ural State University. Series: Mathematics. Mechanics. Physics, 2015, vol. 7, no. 1, pp. 20-27. (in Russian) 
3. Shestakov A.L., Sviridyuk G.A. On the Measurement of the "White Noise". Bulletin of the South Ural State University. Series: Mathematical Modelling, Programming and Computer Software, 2012, no. 27 (286), issue 13, pp. 99-108.

4. Sviridyuk G.A., Manakova N.A. The Dynamical Models of Sobolev Type with Showalter - Sidorov Condition and Additive "Noise". Bulletin of the South Ural State University. Series: Mathematical Modelling, Programming and Computer Software, 2014, vol. 7, no. 1, pp. 90-103. doi: 10.14529/mmp140108 (in Russian)

5. Sviridyuk G.A. On the General Theory of Operator Semigroups. Russian Mathematical Surveys, 1994, vol. 49, no. 4, pp. 45-74. doi: 10.1070/RM1994v049n04ABEH002390

6. Zamyshlyaeva A.A. Stochastic Incomplete Linear Sobolev Type High-Ordered Equations with Additive White Noise. Bulletin of the South Ural State University. Series: Mathematical Modelling, Programming and Computer Software, 2012, no. 40 (299), issue 14, pp. 73-82. (in Russian)

7. Zagrebina S.A., Soldatova E.A. The Linear Sobolev-Type Equations with Relatively p-bounded Operators and Additive White Noise. The Bulletin of Irkutsk State University. Series: Mathematics, 2013, vol. 6, no. 1, pp. 20-34. (in Russian)

Georgy A. Sviridyuk, Doctor Physico-Mathematical Sciences, Professor, Department of Equations of Mathematical Physics, South Ural State University (Chelyabinsk, Russian Federation),sviridyuk@susu.ac.ru

Natalia A. Manakova, Candidate of Physico-Mathematical Sciences, Docent, Department of Equations of Mathematical Physics, South Ural State University (Chelyabinsk, Russian Federation), manakova@susu.ac.ru

\section{МОДЕЛЬ БАРЕНБЛАТТА - ЖЕЛТОВА - КОЧИНОЙ С АДДИТИВНЫМ "БЕЛЫМ ШУМОМ" В КВАЗИСОБОЛЕВЫХ ПРОСТРАНСТВАХ}

\section{Г.А. Свиридюк, Н.А. Манакова}

В статье рассматривается перенос теории линейных стохастических уравнений соболевского типа на квазибанаховы пространства. Для этого строятся пространства дифференцируемых квазисоболевых "шумов" и доказываются существование и единственность классического решения задачи Шоуолтера - Сидорова для стохастического уравнения соболевского типа с относительно р-ограниченным оператором. На основе абстрактных результатов производится исследование стохастической модели Баренблатта - Желтова - Кочиной с начальным условием Шоуолтера - Сидорова в квазисоболевых пространствах с внешним воздействием в виде "белого шума".

Ключевые слова: уравнения соболевского типа, винеровский процесс, производная Нельсона - Гликлиха, "бельй шум"; квазисоболевы пространства, стохастическое уравнение Баренблатта - Желтова - Кочиной. 


\section{Литература}

1. Берг, Й. Интерполяционные пространства. Введение / Й. Берг, Й. Лефстрем. М.: Мир, 1980.

2. Келлер, А.В. Голоморфные вырожденные группы операторов в квазибанаховых пространствах / А.В. Келлер, Д.К. Аль-Делфи // Вестник ЮУрГУ. Серия: Математика. Механика. Физика. - 2015. - Т. 7, № 1. - С. 20-27.

3. Shestakov, A.L. On the Measurement of the "White Noise" / A.L. Shestakov, G.A. Sviridyuk // Вестник ЮУрГУ. Серия: Математическое моделирование и программирование. - 2012. - № 27 (286), вып. 13. - С. 99-108.

4. Свиридюк, Г.А. Динамические модели соболевского типа с условием Шоуолтера Сидорова и аддитивными "шумами" / Г.А. Свиридюк, Н.А. Манакова // Вестник ЮУрГУ. Серия: Математическое моделирование и программирование. - 2014. T. 7, № 1. - C. 90-103.

5. Свиридюк, Г.А. К общей теории полугрупп операторов / Г.А. Свиридюк // Успехи математических наук. - 1994. - Т. 49, № 4. - С. 47-74.

6. Замышляева, А.А. Стохастические неполные линейные уравнения соболевского типа высокого порядка с аддитивным белым шумом / А.А. Замышляева // Вестник ЮУрГУ. Серия: Математическое моделирование и программирование. 2012. - № 40 (299), вып. 14. - С. 73-82.

7. Загребина, С.А. Линейные уравнения соболевского типа с относительно рограниченными операторами и аддитивным белым шумом / C.A. Загребина, Е.А. Солдатова // Известия Иркутского государственного университета. Серия: Математика. - 2013. - Т. 6, № 1. - С. 20-34.

Свиридюк Георгий Анатольевич, доктор физико-математических наук, профессор, заведующий кафедрой уравнений математической физики, ЮжноУральский государственный университет (г. Челябинск, Российская Федерация), sviridyuk@susu.ac.ru

Манакова Наталья Александровна, кандидат физико-математических наук, доцент, кафедра уравнений математической физики, Южно-Уральский государственный университет (г. Челябинск, Российская Федерация), manakova@susu.ac.ru

Поступила в редакиию 9 сентября 2015 г. 